\title{
Pigg-bølge-mønster i EEG?
}

Vi er helt på linje med redaksjonen i Tidsskriftet når de søker å demme opp for den økende anglifiseringen eller amerikaniseringen av fagspråket vårt.

I en artikkel om epilepsi hadde vi skrevet «spike-wave» om den spesielle bølgeformen i EEG som er typisk for epileptiform aktivitet (1). Redaksjonen ønsket at vi fornorsket denne termen og foreslo «piggbølge»- eller «tagg-bølge»-mønster i EEG. Selv om dette hørtes uvant ut, syntes vi forslaget var ganske spenstig.

Vi forhørte oss med med toneangivende epileptologer og nevrofysiologer og fikk følgende reaksjoner:

- Hvaforno?

- Neivettduhva!

- Aprilspøk i november?

- Helt på jordet. Passer best på Hadeland

- Gir assosiasjoner til spesielle korte frisyrer med lyse tupper eller uvær til sjøs

- LOL (laughing out loud) (!)

- Det neste blir vel at vi skal erstatte epilepsibegrepet med fallesyke?

Vi fikk bekreftet at alt nytt ofte blir møtt med motstand og forsøkt latterliggjort. Men vi innser at det er flere problemer med slike oversettelser:
- den engelske termen er allerede godt innarbeidet i fagfeltet

- den norske oversettelsen blir ofte snål og uvant (jf. pub og pøbb, service og sørvis, juice og jus)

- det norske ordet er ikke alltid helt dekkende

Forslaget fra redaksjonen har skapt mye munterhet, og også en del bølger - eller waves - i fagmiljøet. Hva skal vi tilfelle oversette polyspikes med? En trønder foreslo «mang pigga».

\section{Karl 0. Nakken}

karl.otto.nakken@epilepsy.no

Caroline Lund

Avdeling for kompleks epilepsi (SSE)

Oslo universitetssykehus

Postboks 53

1306 Bærum postterminal

\section{Litteratur}

1. Lund C, Brodtkorb E, Nakken KO. LennoxGastauts syndrom - forløp og behandling. Tidsskr Nor Legeforen 2011; 131: 24-7.

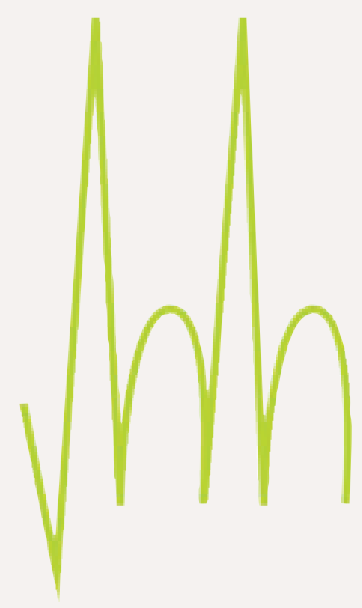

Definisjon fra Store Norske Leksikon Iwww.snl.no/.sml artikkel/elektroencefalografil: «Spike and wave» er en eng. betegnelse for et kortvarig, skarpt utslag koblet til en langsommere bølge.» Det opptrer blant annet hos pasienter med absensepilepsi. Frekvensen er da påca. $3 \mathrm{~Hz}$ 